\title{
Case studies of fluke-induced lesions in mesenteric lymph nodes of Hector's dolphins Cephalorhynchus hectori
}

\author{
J. Hutton ${ }^{1}$, D. Blair ${ }^{2}$, E. Slooten ${ }^{3,4} \&$ S. M. Dawson ${ }^{3,4}$ \\ ${ }^{1}$ Ministry of Agriculture and Fisheries, Animal Health Laboratory, PO Box 24, Lincoln, New Zealand \\ ${ }^{2}$ Department of Zoology, University of Canterbury, Christchurch, New Zealand \\ ${ }^{3}$ CETOS Research, Wainui, R. D. Duvauchelles, Banks Peninsula, New Zealand \\ ${ }^{4}$ Hirnanatomisches Institut, University of Berne, Berne, Switzerland
}

\begin{abstract}
Two Hector's dolphins Cephalorhynchus hectori dissected at Christchurch, New Zealand, in 1985 had granulomatous lesions of the mesenteric lymph node. Histological examination revealed fluke eggs with associated inflammatory responses. In Case 1, a single fluke, probably of the genus Campula (Family Campulidae) was recovered intact from the lesion. A similar fluke was also seen in sections cut of material from Case 2. Bacteriological culture of purulent material from Case 1 yielded Eikenella corrodens, a species apparently previously unknown from marine mammals. The observed pathology was presumably an inflammatory response to the flukes and their eggs, with secondary bacterial infection.
\end{abstract}

\section{INTRODUCTION}

Hector's dolphin Cephalorhynchus hectori is a small species endemic to the coastal waters of New Zealand and most common along the east and west coasts of South Island. It occurs most frequently within 2 nautical miles $(3.7 \mathrm{~km})$ of the shore in small groups of 2 to 8 individuals. Known food items include surface-schooling fish (e.g. kahawai Arripis trutta, yellow-eyed mullet Aldrichetta forsten) and arrow squid Nototadarus sp. along with benthic fish (e.g. red cod Pseudophycis bacchus, ahuru Auchenoceros punctatus and stargazer Crapatalus novaezelandiae) (Slooten \& Dawson in press).

Dolphins incidentally drowned in gillnets or beachcast are routinely dissected. Two mesenteric lymph node lesions described here were discovered in the course of these dissections.

\section{MATERLALS AND METHODS}

Case 1. Adult male dolphin incidentally caught (5 Dec 1985) in a commercial gillnet set in $6 \mathrm{~m}$ of water, $500 \mathrm{~m}$ off New Brighton Beach, near Christchurch on the east coast of the South Island of New Zealand $\left(43^{\circ} 30.6^{\prime} \mathrm{S}, 172^{\circ} 44.4^{\prime} \mathrm{E}\right)$ and dissected within $23 \mathrm{~h}$ of death.

Case 2. Adult female dolphin similarily caught (early 1985) in a commercial gill net set in $15 \mathrm{~m}$ of water off Gillespies Point $\left(43^{\circ} 23^{\prime} \mathrm{S}, 169^{\circ} 52^{\prime} \mathrm{E}\right)$ on the west coast of the South Island. This specimen had been frozen for several months before dissection.

Mesenteric and other lymph node tissue samples taken for histological examination were fixed in $10 \%$ formalin, cut at $5 \mu \mathrm{m}$ and stained with haematoxylin and eosin

The necrotic lesion in Case 1 was bacteriologically cultured on $5 \%$ sheep blood agar at $37^{\circ} \mathrm{C}$ both aerobically and in an atmosphere of 5 to $10 \% \mathrm{CO}_{2}$.

The fluke recovered from the Case 1 mesenteric lymph node was fixed in $10 \%$ formalin; stained with Gower's carmine, dehydrated, cleared and mounted in Canada balsam. It has been deposited in the National Museum of New Zealand, Wellington (No. ZW 1190).

\section{RESULTS}

\section{Gross pathology}

Case 1. The mesenteric lymph node was enlarged with a large $(7.0 \times 4.0 \times 2.0 \mathrm{~cm})$ tumour-like mass at 

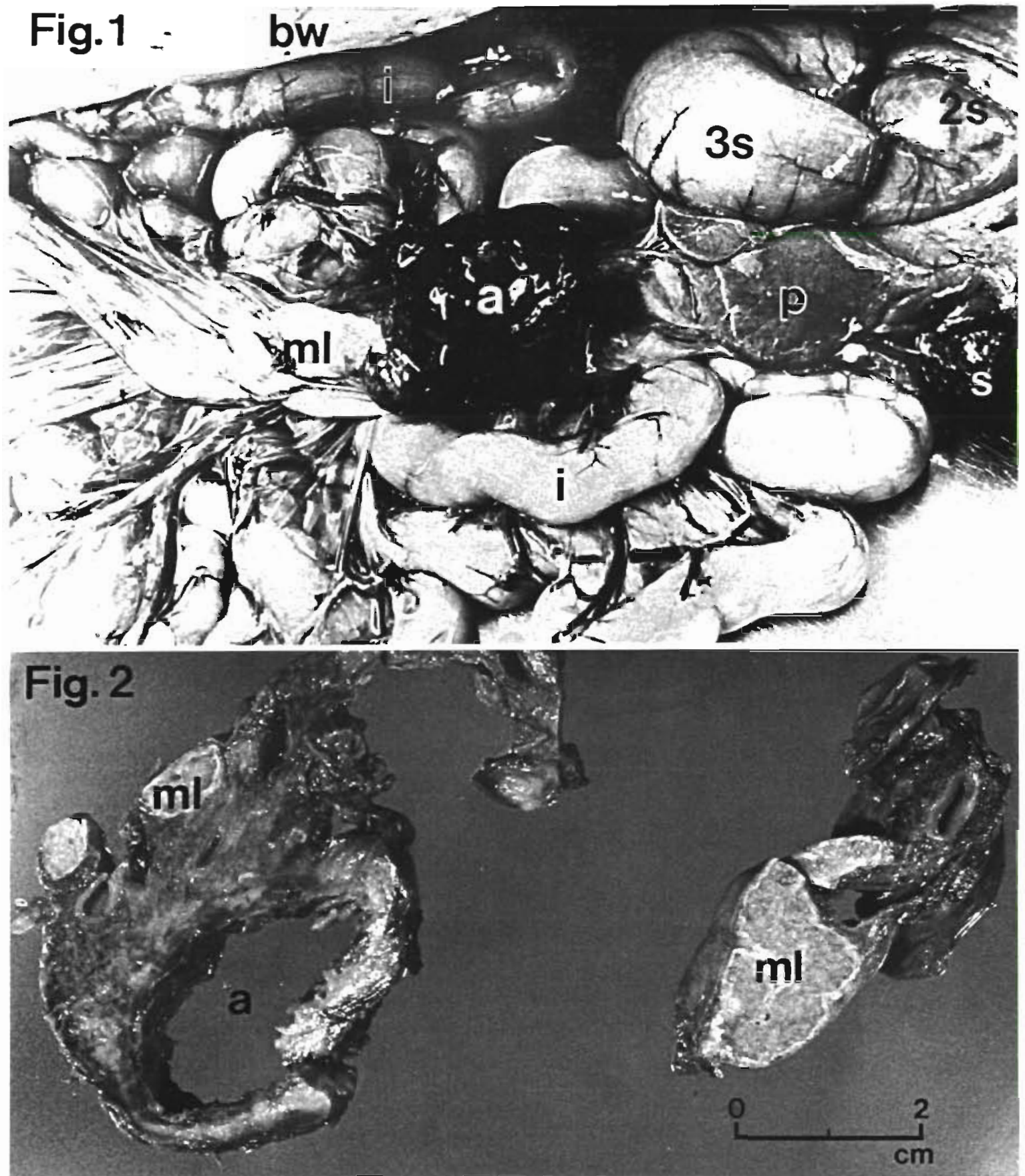

Fig. 1 \& 2. Cephalorhynchus hectori. Fig. 1. Parasite-induced tumour-like lesion of the mesenteric lymph node (Case 1.) a: lesion; bw: body wall; i: intestine; ml: mesenteric lymph node; $p$ : pancreas; $s, 2 s, 3 s$ : stomach. Fig. 2 . Cross-section of the lesion (left) and adjacent mesenteric lymph node (right) (Case 1) after formalin fixation. The necrotic material has been removed from the centre of the lesion and only a small amount of lymphoid tissue remains at the level of the lesion. Legend as for Fig. 1

its anterior end (Fig. 1), and several smaller $(1$ to $2 \mathrm{~cm}$ ) masses protruding from beneath the lymph node capsule (Fig. 2). On cross-section, the larger mass contained purulent necrotic debris and a single parasitic worm. No further parasites were found in any of the lesions, each of which had fibrous outer margins and inspissated brown necrotic material centrally.
Case 2. The mesenteric lymph node was slightly enlarged and contained about 5 lesions, 1 to $2 \mathrm{~cm}$ across, bulging the capsule of the node. When cut, the lesions were similar to the smaller lesions of Case 1. 


\section{Parasitology}

Case 1. The parasitic worm was a fluke (digenean) of the genus Campula (family Campulidae) (see 'Discussion'). It measured $7.1 \times 1 \mathrm{~mm}$. Although apparently dead when found, it showed no signs of degeneration.

Case 2. Serial sections through one lesion revealed an adult fluke and many fluke eggs similar to those seen in Case 1. The anatomy of the worm, traced as far as possible through the sections, resembled that of the intact worm seen in Case 1.

\section{Bacteriology}

Case 1. A pure growth of Eikenella corrodens was obtained from the lesion.

\section{Histopathology}

Case 1. The lesions within the lymph node were parasite-induced granulomata which replaced the lymphoid tissue locally. The larger lesion (Fig. 1) had a central area of necrosis containing cellular debris, inflammatory cells and fluke eggs triangular in section. The fluke eggs measured 30 to $36 \mu \mathrm{m}$ across and many had a distinctive yellow outer membrane. The inflammatory reaction around the eggs included macrophages often containing haemosiderin, multinucleated giant cells and eosinophils. Many eggs were being broken down by the granulomatous inflammatory reaction and multinucleated giant cells were present around and inside degenerating eggs. In some areas, the eggs had disappeared and collections of giant cells and haemosiderin-laden macrophages were all that remained.

Case 2. The lesions were similar to the smaller lesions of Case 1 with central necrosis and inflammation. However, the lesions were not as advanced and the giant cell reaction was less prominent than in Case 1. Sections through one lesion included part of an adult fluke and many fluke eggs similar to those seen in Case 1.

\section{DISCUSSION}

The single intact fluke found appears to belong to the genus Campula. It has caeca with a pair of conspicuous anterior diverticula, ventral sucker in anterior third of body similar in size to oral sucker, unarmed terminal genitalia, ovary not highly lobate, vitellaria extensive between ventral sucker and posterior end of body, and eggs triangular in cross-section. Identification to species level is not possible.

Campula species and related genera in the families
Campulidae and Nasitrematidae occur commonly in dolphins in the liver, pancreas, and the ducts draining these (Yamaguti 1971) (in dolphins, bile and pancreatic ducts unite into a common duct before entering the intestine). Pathological changes in these organs as a consequence of fluke infections have been described (e.g. Woodard et al. 1969, McColl \& Obendorf 1982).

Such flukes also occur in tissue sites. In particular, adult flukes and/or their eggs have been found in the brains of dolphins where they cause severe pathology (Woodard et al. 1969, Ridgway \& Dailey 1972, Dailey \& Walker 1978). Associated bacterial infection was not recorded in these cases. No previous records have been found of campulid flukes in lymph nodes, although Ridgway \& Dailey (1972) described black spots in mesenteric lymph nodes of dolphins Delphinus sp. which had campulid flukes in the liver and pancreas. These spots were foci of haemosiderin-laden macrophages. No flukes or their eggs were described.

Eggs of campulids stimulate severe inflammatory responses (Kumar et al. 1975). In the cases reported here, its seems likely that the primary causes of the marked mesenteric lymph node inflammatory and necrotic granulomatous responses were the fluke eggs deposited within the node. Presumably the bacterial infection in Case 1 was a secondary event.

To our knowledge, there have been no previous reports of Eikenella corrodens from a marine mammal. This is a $\mathrm{CO}_{2}$-dependent bacterium seen in infections of cattle and humans. It is rarely pathogenic, but has been found in wound infections, liver abscesses and in cases of peritonitis. It is usually regarded as an opportunistic pathogen and can produce infections in compromised hosts (Jackson \& Goodman 1984). In the case reported above, it was probably an opportunistic organism present in the lymph node because of the inflammation already set up by the parasite.

Acknowledgements. We thank the staff of the Lincoln Animal Health Laboratory for generously providing facilities for dissection and examination of specimens. We also thank Jan McKenzie for her freely given time, assistance with dissections and identification of other parasites. Hector's dolphin research by Slooten and Dawson is partly funded by Project Jonah New Zealand (Inc.), the New Zealand Lottery Board, Pacific Whale Foundation, Cetaceans Society International, World Wildlife Fund (N.Z.), Oceans Society of New Zealand (Inc.) and IBM (New Zealand) Ltd. Neptune Aquasuits, David Reid Electronics Ltd, Tait Electronics, Hutcheson Wilson and Co. Ltd, Neill Cropper and Co. Ltd and Anthoni Computer Automations Ltd have provided equipment for their field work.

\section{LITERATURE CITED}

Dailey, M. D., Walker, W. A. (1978). Parasitism as a factor (?) in single strandings of southern California cetaceans. J. Parasitol. 64: 593-596

Jackson, F. L., Goodman, Y. (1984). Genus Eikenella Jackson 
and Goodman 1972. In: Krieg, N. (ed.) Bergey's manual of systematic bacteriology, Vol. 1. Williams \& Wilkins, Baltimore, London, p. 591-597

Kumar, V., Vercruysse, J., Kageruka, P., Mortelmans, J. (1975). Nasitrema attenuata (Trematoda) infection of Tursiops truncatus and its potentialities as an aetiological agent of chronic pulmonary lesions. J. Helminthol. 49: 289-292

McColl, K. A., Obendorf, D. L. (1982). Helminth parasites and associated pathology in stranded Fraser's dolphins, Lagenodelphis hosei (Fraser, 1956). Aquat. Mamm. 9: $30-34$
Ridgway, S. H., Dailey, M. D. (1972). Cerebral and cerebellar involvement of trematode parasites in dolphins and their possible role in stranding. J. WildI. Dis. 8: $33-43$

Slooten, E., Dawson, S. M. (in press). Hector's dolphin. In Ridgway, S. H., Harrison, R. (ed.) Handbook of marine manmals, Vol. 5. Academic Press, New York

Woodard, J. C., Zam, S. G., Caldwell, D. K., Caldwell, M. C. (1969). Some parasitic diseases of dolphins. Path. Vet. 6: $257-272$

Yamaguti, S. (1971). Synopsis of the digenetic trematodes of vertebrates. Keigaku Publishing Co, Tokyo 